\title{
Erratum to: Review of the nutritional benefits and risks related to intense sweeteners
}

Olivier Bruyère ${ }^{1 *}$, Serge H. Ahmed ${ }^{2}$, Catherine Atlan ${ }^{3}$, Jacques Belegaud ${ }^{4}$, Murielle Bortolotti ${ }^{5}$, Marie-Chantal Canivenc-Lavier ${ }^{6}$, Sybil Charrière ${ }^{7}$, Jean-Philippe Girardet ${ }^{8}$, Sabine Houdart ${ }^{9}$, Esther Kalonji ${ }^{9}$, Perrine Nadaud ${ }^{9}$, Fabienne Rajas $^{10}$, Gérard Slama ${ }^{11}$ and Irène Margaritis ${ }^{9}$

Unfortunately, the original version of this article [1] contained an error.

The author's names were included incorrectly, the surnames were presented before the forename:

Bruyère Olivier, Ahmed H. Serge, Atlan Catherine, Belegaud Jacques, Bortolotti Murielle, Canivenc-Lavier Marie-Chantal, Charrière Sybil, Girardet Jean-Philippe, Houdart Sabine, Kalonji Esther, Nadaud Perrine, Rajas Fabienne, Slama Gérard and Margaritis Irène

The author list has been corrected in the original article and is also included correctly below:

Olivier Bruyère, Serge H. Ahmed, Catherine Atlan, Jacques Belegaud, Murielle Bortolotti, Marie-Chantal Canivenc-Lavier, Sybil Charrière, Jean-Philippe Girardet, Sabine Houdart, Esther Kalonji, Perrine Nadaud, Fabienne Rajas, Gérard Slama, Irène Margaritis

\begin{abstract}
Author details
'Department of Public Health, Epidemiology and Health Economics, University of Liege, CHU Sart Tilman, Bât B23, 4000 Liège, Belgium. ${ }^{2}$ CNRS UMR 5293/Université de Bordeaux, Bordeaux, France. ${ }^{3}$ Centre Hospitalier de Luxembourg, Luxembourg, Luxembourg. ${ }^{4}$ Université de Picardie, Amiens, France. ${ }^{5}$ Centre Hospitalier Universitaire Vaudois, Lausanne, Suisse, Switzerland. ${ }^{6}$ Centre des Sciences du Goût et de I'Alimentation - INRA Dijon, Dijon, France. ${ }^{7}$ Université Claude Bernard Lyon 1, Hospices Civils de Lyon, Inserm U1060, Lyon, France. ${ }^{8}$ Sorbonne Universités, UPMC Univ Paris 06, Paris, France. ${ }^{9}$ French Agency for Food, Environmental and Occupational Health \& Safety (Anses), Maisons-Alfort, France. ${ }^{10}$ INSERM 855/Université Claude Bernard Lyon 1, Lyon, France. ${ }^{11}$ Hôtel-Dieu Hospital, René Descartes University-Paris V, Paris, France.
\end{abstract}

Accepted: 5 October 2015

Published online: 23 October 2015

\section{Reference}

1. Bruyère $B$ et al. Review of the nutritional benefits and risks related to intense sweeteners. Arch Public Health. 2015;73:41.

\author{
Submit your next manuscript to BioMed Central \\ and take full advantage of: \\ - Convenient online submission \\ - Thorough peer review \\ - No space constraints or color figure charges \\ - Immediate publication on acceptance \\ - Inclusion in PubMed, CAS, Scopus and Google Scholar \\ - Research which is freely available for redistribution
}

Submit your manuscript at

www.biomedcentral.com/submit

() Biomed Central

\footnotetext{
'Department of Public Health, Epidemiology and Health Economics, University of Liege, CHU Sart Tilman, Bât B23, 4000 Liège, Belgium Full list of author information is available at the end of the article
} 